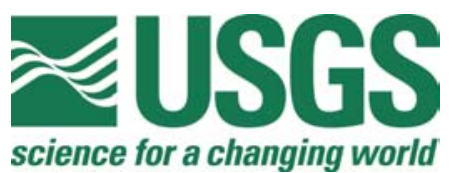

\title{
Mineral deposit data for epigenetic base- and precious-metal and uranium-thorium deposits in south-central and southwestern Montana and southern and central Idaho
}

By T.L. Klein

This report is preliminary and has not been reviewed for conformity with U.S. Geological survey editorial standards.

Any use of trade, product, or firm names is for descriptive purposes only and does not imply endorsement by the U.S. Government.

Open File Report 2004-1005

U.S. Department of the Interior

U.S. Geological Survey 


\section{Contents}

Introduction

Data Sources

Database

References

Figures

Figure 1. Location of study area

Tables

Table 1. Primary data sources

Table 2. Database field descriptions

Table 3. Explanation of codes used in database

Spreadsheet - Epigenetic deposits Montana and Idaho

Spreadsheet - Reference for database spreadsheet 


\title{
Mineral deposit data for epigenetic base- and precious-metal and uranium-thorium deposits in south-central and southwestern Montana and southern and central Idaho
}

\author{
By T.L. Klein
}

\section{Introduction}

Metal deposits spatially associated with the Cretaceous Boulder and Idaho batholiths of southwestern Montana and southern and central Idaho have been exploited since the early 1860 's. Au was first discovered in placer deposits; exploitation of vein deposits in bedrock soon followed. In 1865, high-grade Ag vein deposits were discovered and remained economically important until the 1890's. Early high-grade deposits of $\mathrm{Au}, \mathrm{Ag}$ and $\mathrm{Pb}$ were found in the weathered portions of the veins systems. As mining progressed to deeper levels, $\mathrm{Ag}$ and $\mathrm{Pb}$ grades diminished. Exploration for and development of these vein deposits in this area have continued until the present. A majority of these base- and precious-metal vein deposits are classified as polymetallic veins (PMV) and polymetallic carbonate-replacement (PMR) deposits in this compilation. Porphyry $\mathrm{Cu}$ and $\mathrm{Mo}$, epithermal ( $\mathrm{Au}, \mathrm{Ag}, \mathrm{Hg}$ and $\mathrm{Sb}$ ), base- and preciousmetal and $\mathrm{W}$ skarn, $\mathrm{W}$ vein, and $\mathrm{U}$ and $\mathrm{Th}$ vein deposits are also common in this area. The world-class Butte $\mathrm{Cu}$ porphyry and the Butte high-sulfidation $\mathrm{Cu}$ vein deposits are in this study area. PMV and PMR deposits are the most numerous in the region and constitute about $85 \%$ of the deposit records compiled. Several types of syngenetic/diagenetic sulfide mineral deposits in rocks of the Belt Supergroup or their equivalents are common in the region and they have been the source of a substantial metal production over the last century. These syngenetic deposits and their metamorphosed/structurally remobilized equivalents were not included in this database; therefore, deposits in the Idaho portion of the Coeur d'Alene district and the Idaho Cobalt belt, for example, have not been included because many of them are believed to be of this type.

More than 3,300 epigenetic mineral deposits are included in this compilation (fig. 1). More than 1600 of these deposits either have produced metal or have unexploited resources. Mineral deposit information in this database is summarized in 39 fields and is presented in an Excel spreadsheet file format. This database was compiled for metallogenic studies, grade and tonnage model development, and mineral resource assessments for metal deposits in the region. This information was compiled as part of a USGS study of central and western Montana and Idaho (Headwaters Project), which was undertaken, in part, to provide geologic and mineral resource information and geologic interpretations for the Department of Agriculture-Forest Service for use in land management.

\section{Data Sources}

The information contained in this database was primarily derived from mineral resource information extracted from the Mineral Resource Data System (MRDS) of the U.S. Geological Survey. This information was supplemented from several primary data sources that are listed in Table 1. Many of these reports listed in Table 1 contain information from the Conterminous United States Mineral Assessment Program (CUSMAP). The purpose of the CUSMAP studies was to assess the mineral resource potential at a scale of 1:250,000 for areas covered in the U.S. Geological Survey $1^{\circ} \times 2^{\circ}$ 
topographic quadrangles series conducted in the 1970's and 1980's. The Butte, Challis, Dillon, Hailey, and Idaho Falls $1^{\circ}$ x $2^{\circ}$ topographic quadrangles were assessed under this program. Location, geologic, and production information from mineral resources assessments for the Challis, Gallatin, Helena, Payette, Salmon and Targhee National Forests were also used to supplement original MRDS data. Additional mineral production and geologic information were obtained from reports of the Montana Bureau of Mines and Geology and the Idaho Bureau of Mines and Geology, the Securities and Exchange Commission EDGAR database website (http://www.sec.gov/edgar/edgarsearch/webusers.htm), and the many National Forest Wilderness area reports (Table 1) that were completed in the area by the USGS and Mineral Land Assessments (MLA) completed by the U.S. Bureau of Mines in the 1970's and 1980's. Production data from Bliss (1994), Long and others (1998), and Spanski (2004) were used extensively for the economically significant deposits in the study area.

Table 1: Primary data sources for database upgrades

\begin{tabular}{|l|l|l|}
\hline Area Name & Investigation type & Reference \\
\hline Butte & CUSMAP & Elliot and others (1992) \\
\hline Challis & CUSMAP & $\begin{array}{l}\text { Fisher and Johnson (1995); Wilson, A.B. } \\
\text { (unpublished data) }\end{array}$ \\
\hline Dillon & CUSMAP & Loen and Pearson (1989) \\
\hline Hailey & CUSMAP & Worl and others (1995) \\
\hline Idaho Falls & CUSMAP & Worl and others (1995) \\
\hline Challis & National Forest & $\begin{array}{l}\text { McHugh and others (1991), MLA prepared } \\
\text { for the Challis National Forest }\end{array}$ \\
\hline Helena & National Forest & Tysdal and others (1996) \\
\hline Payette & National Forest & Bookstrom and others (1998) \\
\hline Salmon & National Forest & Johnson and others (1998) \\
\hline Targhee & National Forest & Kness (1995) \\
\hline
\end{tabular}

Mineral deposit locations, as noted above, were revised from many sources. MRDS locations were updated where more reliable information was available; a comprehensive update of locations was not a primary objective of this compilation and was not undertaken due to time constraints. Much of the data used for revisions and new records was obtained from the various USGS and USBM National Forest mineral resource assessments (table 1) and unpublished information from U.S. Geological Survey investigators who have extensive field experience in the region. These include, A.A. Bookstrom, R.G. Eppinger, K.V. Evans, and B. Van Gosen. 


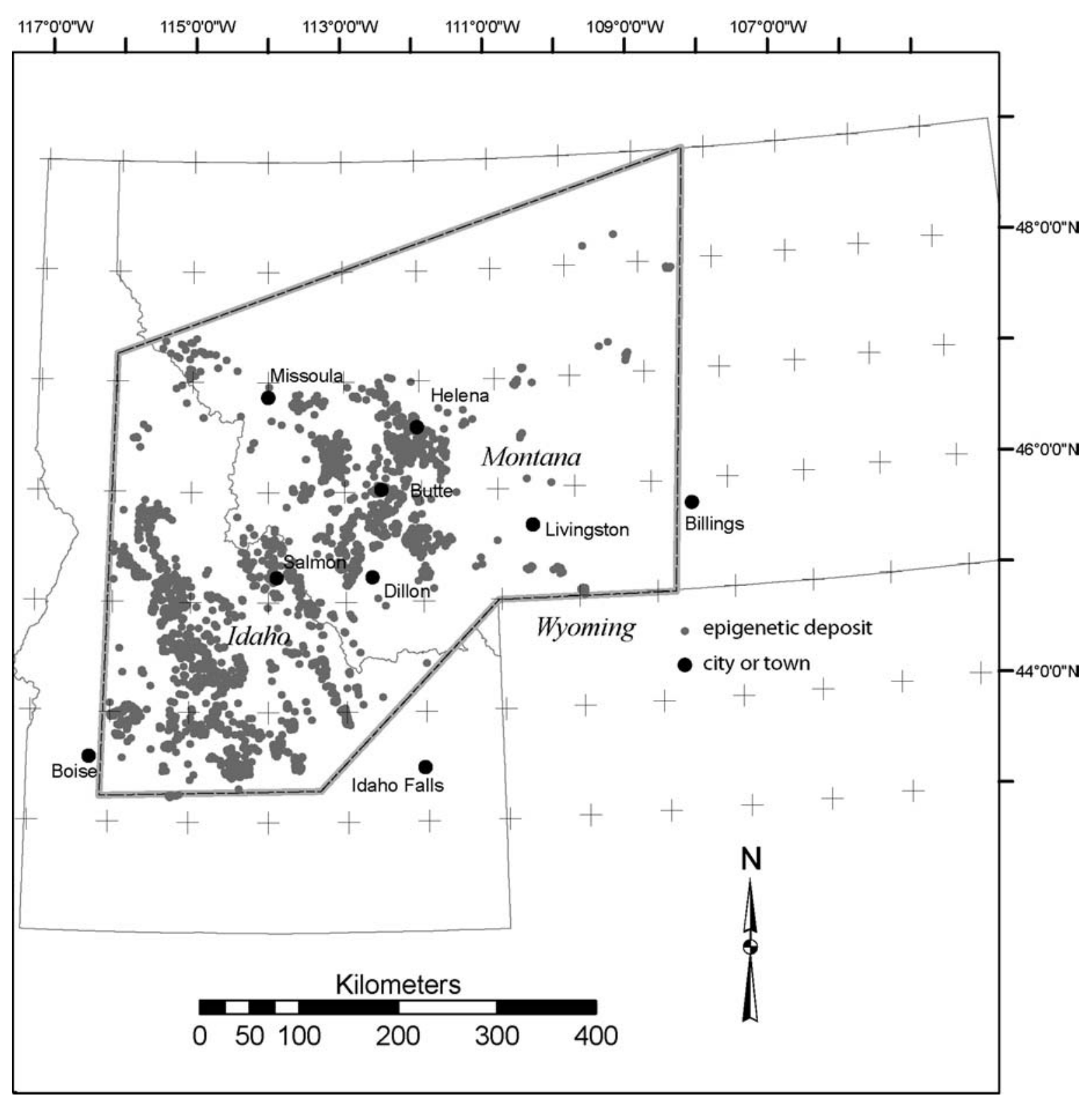

Figure 1. Location of the epigenetic mineral deposits in study area. The thick gray line is the study area boundary.

\section{Database}

The data presented here was retrieved from the MRDS database in May 2000 and subsequently modified by removing unwanted fields, adding data in new fields, and updating information in many of the original fields. The spreadsheet contains data in 39 fields that summarizes characteristics of epigenetic metal, $U$ and Th deposits that may aid in predicting areas of future mineral development and assessing mineral resource potential in the study area. The database field names are defined in table 2 and the codes that are used in some of the fields are listed in table 3. The following paragraphs are included to clarify some of the function of or the information contained in the database. 
The original MRDS reference numbers were retained in the MRDS field. New records that were added to the database do not have entries in this field. When multiple names appear in the deposit field the MRDS number for the largest deposit was retained in the MRDS field.

One of the primary purposes of this database is to provide revised production data for mineral deposit grade and tonnage modeling. When compiling data for this purpose, a "deposit" must be defined so that the production and resource data are reported consistently (see Cox and Singer (1986). For this study a "deposit" described in a record consists of all mines and prospects that are located within approximately $0.5 \mathrm{~km}$ perpendicular to known mineralized trend or structure and are within $1 \mathrm{~km}$ of one another, along the strike of the trend if they have similar physical characteristic and (or) are apparently genetically related. The individual mines that were combined, as deposits, are all listed as multiple entries in the deposit field. Alternate deposit names are reported in the synonym field.

The metals field is multi-valued and identifies the commodities that are present in the deposit. These are listed in the approximate order of their abundances. The order of these metals is largely retained from the MRDS database and was not routinely modified. Some revisions were made during this compilation where information was available. The production or resources field indicates whether the deposit has recorded production or contains resources. The significant field indicates whether or not the deposit meets the significant deposit criteria of Long and others (1998) for at least one of the contained metals.

The USGS descriptive model is the mineral deposit model number following the nomenclature used by Cox and Singer (1986) and Bliss (1992). Model numbers in this database were assigned using the geologic information that was available for each deposit. Sufficient information was available for most of the larger deposits in the database to allow classification. However, records in many of the existing databases, such as MRDS, MAS, and the various National Forest mineral deposit compilations (table 1) for many of the smaller deposits contained only location information with insufficient geologic information or references to allow their classification. Several deposit types, such as the Butte $\mathrm{Cu}$ veins and Butte $\mathrm{Ag}$ veins, do not have descriptive models available. Multiple entries in this field indicate that the geologic information available does not permit the discrimination between the listed models.

The deposit type field contains a more generalized classification than the USGS descriptive model field that is a less restrictive classification and may be more widely useful where model identification is lacking or geologic information is not available to make distinctions between descriptive models.

The two deposit types, the PMV and PMR comprise, by far, the largest number of deposits in the study area. Grade and tonnage modeling of these deposits is complicated by their polymetallic character. Metals that are primary components in some deposits may have one mean or median metal grade whereas the median or mean grades for the same metals in other deposits may be different where they are byproducts or co-products even though all the deposits may be of the same type. Bliss (1994), in a study of PMV deposits in the southern part of the Idaho Batholith, developed a value component approach to modeling these complex metallic mineral deposits. The method uses the amount of each metal produced and a price for that metal to calculate a total value for 
each metal produced. The values for all the metals are totaled and the value for each metal is normalized with the total deposit value to give a value-base proportion of each metal to the total deposit value. The deposit classes for this compilation used in the value category field were then assigned based on the proportion of each metal value. Bliss classified the deposits in the Idaho Batholith with six component types; byproducts $(B)$ and co-products $(C)$ are listed in parentheses; 1$) \mathrm{Au}(B ; \mathrm{Ag}, \mathrm{Cu}, \mathrm{Pb}, \mathrm{Zn}), 2) \mathrm{Ag}(C$; $\mathrm{Au}, B$; $\mathrm{Au}, \mathrm{Cu}, \mathrm{Pb}, \mathrm{Zn}), 3) \mathrm{Ag}-\mathrm{Pb}(B ; \mathrm{Au}, \mathrm{Cu}, \mathrm{Zn}), 4) \mathrm{Cu}(C ; \mathrm{Au}: B ; \mathrm{Au}, \mathrm{Ag}, \mathrm{Pb}, \mathrm{Zn}), 5)$ $\mathrm{Cu}-\mathrm{Pb}-\mathrm{Zn}(C ; \mathrm{Ag} ; B ; \mathrm{Au}), 6) \mathrm{Sb}(B ; \mathrm{Au}, \mathrm{Ag})$.

Similar classes have been used to describe the PMV and PMR deposits in this compilation with the addition of a seventh class which contained a few deposits that produced only $\mathrm{Zn}$. These classes can be used to determine metal zoning at district and regional scales. For this compilation mean metal values for $\mathrm{Ag}, \mathrm{Pb}$, and $\mathrm{Cu}$ between 1900 and 1930 (0.64, 0.06, and $0.18 \$ / 1 \mathrm{~b}$, respectively); mean metal prices for Zn were calculated for the interval 1909-1930 (\$0.06/lb). Au values were calculated at $\$$ $20.67 /$ troy ounce. These $\mathrm{Ag}, \mathrm{Cu}, \mathrm{Pb}$, and $\mathrm{Zn}$ metal values differ slightly from those used by Bliss (1994). In some cases, where the metals field was single valued or unambiguous and there was no production or resource data, a value category was assigned on the basis of the metals field. Skarn/contact metamorphic deposits, which also may contain multiple metals, were qualitatively classified based on available production or mineralogical data.

Codes in the deposit style field indicate the physical style of metallic mineralization. These include descriptors such as vein, disseminated, and manto. The term of "hot spring-disseminated precious metal deposit" was used where there was evidence of disseminated, shallow level, epithermal precious-metal mineralization. This field was included as an aid in determining whether deposits represent bulk-mineable exploration targets. Rock type indicates the general character of the host rocks; for example, whether they are clastic sedimentary, carbonate rocks, or volcanic rocks. The host rock field was largely derived from information in the MRDS database. This is a multi-value field with commas used as a delimiter. This data field in MRDS contained numerous inconsistent lithologic terms and some mixed rock and formation names. An attempt was made to correct some of the inconsistencies in this data field. However, a complete revision was not attempted due to lack of appropriate information, in some cases, and time constraints. Host rock age contains the stratigraphic age of the host rock. The multiple values in this field (comma delimited) are related to the multiple values for host rock. These ages are largely derived from MRDS; some updates were accomplished by plotting deposit locations on digital state geologic maps of Montana and Idaho (Raines and Johnson, 1995; Johnson and Raines, 1995). The associated igneous rocks field contains the lithologic names of intrusive or volcanic rocks that occur near or within the ore deposit but that are not a major host rock for the deposit. Igneous age is the stratigraphic age or radiometric age (where available) for the associated igneous rocks field. Mineralization age contains stratigraphic age or radiometric ages of the mineral deposits. The mining district field gives the mining district or mineralized area that contains the deposit. The districts are based on the Idaho mining district map (Gustafson, 1987) and the mining areas of Montana map of Lee and others (2000). This field has been extensively updated using GIS district boundary maps. 
Many of the original geographic locations in MRDS were derived from township, range, and section data based on the Public Land Survey System (PLSS). A substantial effort was made during this compilation to upgrade location data (latd, longd) available from the many mineral resource studies in the region, which provided locations digitized from locations plotted on topographic maps. The PLSS-derived geographic location data was replaced by topographic map-based data wherever it was available during this compilation. All revised locations were digitized using the NAD 27 datum. It is assumed that most of the original MRDS were also derived using the NAD 27 datum because many of the records were input before the NAD 83 datum was established. Locations for most of the records in this database locate or are assumed to locate the major production shaft at a mine site or the principle prospect excavation, although there are some irresolvable inconsistencies in the database.

The reference number field contains a number that refers to major references for each deposit listed in the separate References spreadsheet. Semicolons were used to delimit each reference; commas delimit relevant page numbers within the reference. Most records in the database include some reference information. However, many of the original MRDS records do not contain references. References were found for some of these during this compilation but reliable reference information for most of the unreferenced records was not found. Where MRDS references were found to be invalid they were corrected or deleted when an appropriate one could not be found.

Quantitative data summarized in the field for metric tons and data for the metal fields is mostly production data. However, when data for identified resources was available they were included with the production data to provide an estimate of the total metal endowment for a deposit; details concerning the combined data are found in the production and resources source reference and comments field. Information for other metal production or resources $(\mathrm{W}, \mathrm{Sb}, \mathrm{Fe}$, and $\mathrm{Mn}$ ) such as contained in some of these deposits is summarized in the comments field. 
Table 2. Database field descriptions

\begin{tabular}{|c|c|c|c|}
\hline Field Name & Description & Units & Update comments \\
\hline MRDS & $\begin{array}{l}\text { MRDS reference } \\
\text { number }\end{array}$ & & \\
\hline deposit & mineral deposit name & & $\begin{array}{l}\text { names have been } \\
\text { combined to define } \\
\text { "deposits" rather than } \\
\text { individual mines }\end{array}$ \\
\hline synonym & alternate name & & \\
\hline state & state name & & \\
\hline metals & $\begin{array}{l}\text { principal metals } \\
\text { contained in the } \\
\text { deposit derived from } \\
\text { assays, production } \\
\text { data, or mineralogy } \\
\text { of the deposit; } \\
\text { generally in the order } \\
\text { of abundance; multi- } \\
\text { valued, space- } \\
\text { delimited }\end{array}$ & & some revisions \\
\hline production or resources & $\begin{array}{l}\text { indicates if metals } \\
\text { were produced or the } \\
\text { deposit has resources }\end{array}$ & & revised \\
\hline significant & $\begin{array}{l}\text { indicates if the } \\
\text { deposit is } \\
\text { economically } \\
\text { significant based on } \\
\text { the criteria of Long } \\
\text { and others (1998) }\end{array}$ & & new data \\
\hline $\begin{array}{l}\text { USGS } \\
\text { descriptive model }\end{array}$ & $\begin{array}{l}\text { U.S. Geological } \\
\text { Survey descriptive } \\
\text { mineral deposit } \\
\text { model number (Cox } \\
\text { and Singer, 1986; } \\
\text { Bliss, 1992); null } \\
\text { indicates data are } \\
\text { insufficient to } \\
\text { classify deposit or } \\
\text { deposit models are } \\
\text { not suitable for } \\
\text { classification; multi- } \\
\text { valued, space- } \\
\text { delimited }\end{array}$ & & new classification \\
\hline
\end{tabular}


Table 2. (continued)

\begin{tabular}{|c|c|c|c|}
\hline Field Name & Description & Units & Update comments \\
\hline deposit type & $\begin{array}{l}\text { code for general } \\
\text { mineral deposit type; } \\
\text { multi-valued, space- } \\
\text { delimited }\end{array}$ & & new classification; \\
\hline value category & $\begin{array}{l}\text { metal value-based } \\
\text { classification of } \\
\text { polymetallic vein, } \\
\text { replacement deposits } \\
\text { and skarn deposits } \\
\text { (based on the method } \\
\text { of Bliss (1994)); } \\
\text { multi-valued, space- } \\
\text { delimited, } \\
\end{array}$ & & new classification \\
\hline deposit style & $\begin{array}{l}\text { code for physical } \\
\text { style of mineralized } \\
\text { area }\end{array}$ & & new classification \\
\hline rock type & $\begin{array}{l}\text { code for general host } \\
\text { rock type; multi- } \\
\text { valued, comma- } \\
\text { delimited }\end{array}$ & & new classification \\
\hline host rock & $\begin{array}{l}\text { specific host rock } \\
\text { name; in some cases } \\
\text { rock unit name was } \\
\text { retained from MRDS; } \\
\text { multi-valued field, } \\
\text { comma-delimited }\end{array}$ & & some revisions \\
\hline host rock age & $\begin{array}{l}\text { stratigraphic age of } \\
\text { host rock; the order } \\
\text { of corresponds to host } \\
\text { rock field; multi- } \\
\text { valued field, comma- } \\
\text { delimited }\end{array}$ & & some additions \\
\hline associated igneous rock & $\begin{array}{l}\text { associated igneous } \\
\text { rock name or rock } \\
\text { unit }\end{array}$ & & some additions \\
\hline igneous age & $\begin{array}{l}\text { stratigraphic or } \\
\text { geochronologic age } \\
\text { of associated igneous } \\
\text { rocks }\end{array}$ & & new data \\
\hline mineralization age & $\begin{array}{l}\text { geochronologic age } \\
\text { of mineral deposit }\end{array}$ & $\begin{array}{l}\text { millions of } \\
\text { years }\end{array}$ & new data \\
\hline mining district & $\begin{array}{l}\text { mining district or area } \\
\text { name }\end{array}$ & & $\begin{array}{l}\text { extensive revisions } \\
\text { and additions }\end{array}$ \\
\hline
\end{tabular}


Table 2. (continued)

\begin{tabular}{|c|c|c|c|}
\hline Field Name & Description & Units & Update comments \\
\hline latdd & latitude of deposit & $\begin{array}{l}\text { decimal } \\
\text { degrees } \\
\text { (north } \\
\text { latitude) }\end{array}$ & $\begin{array}{l}\text { some MRDS locations } \\
\text { were revised }\end{array}$ \\
\hline longdd & longitude of deposit & $\begin{array}{l}\text { decimal } \\
\text { degrees } \\
\text { (west } \\
\text { longitude) }\end{array}$ & $\begin{array}{l}\text { some MRDS locations } \\
\text { were revised }\end{array}$ \\
\hline reference number & $\begin{array}{l}\text { numbers for } \\
\text { references; multi- } \\
\text { valued, semicolon- } \\
\text { delimited }\end{array}$ & $\begin{array}{l}\text { reference } \\
\text { number, } \\
\text { page } \\
\text { number; } \\
\text { reference } \\
\text { number }\end{array}$ & \\
\hline comments & $\begin{array}{l}\text { explanatory notes or } \\
\text { additional } \\
\text { information } \\
\text { concerning deposit } \\
\text { characteristics }\end{array}$ & & \\
\hline discovery year & $\begin{array}{l}\text { year of discovery of } \\
\text { deposit }\end{array}$ & & revised \\
\hline production start & $\begin{array}{l}\text { first recorded year of } \\
\text { production }\end{array}$ & & revised \\
\hline production years & $\begin{array}{l}\text { time interval of the } \\
\text { quantitative } \\
\text { production data, in } \\
\text { columns AA through } \\
\text { AM }\end{array}$ & years & new data \\
\hline metric tons & $\begin{array}{l}\text { amount of ore } \\
\text { produced or resources } \\
\text { estimated }\end{array}$ & $\begin{array}{l}\text { metric } \\
\text { tons }\end{array}$ & new and revised data \\
\hline grade $\mathrm{Au}$ & gold grade & $\mathrm{g} / \mathrm{t} \mathrm{Au}$ & new and revised data \\
\hline $\mathrm{Au} \_\mathrm{g}$ & $\begin{array}{l}\text { amount of gold } \\
\text { produced or } \\
\text { estimated as a } \\
\text { resource }\end{array}$ & $\mathrm{g}$ & new and revised data \\
\hline grade $\mathrm{Ag}$ & silver grade & $\mathrm{g} / \mathrm{t} \mathrm{Ag}$ & new and revised data \\
\hline $\mathrm{Ag} \_\mathrm{g}$ & $\begin{array}{l}\text { amount of silver } \\
\text { produced or } \\
\text { estimated as a } \\
\text { resource }\end{array}$ & $\mathrm{g}$ & new and revised data \\
\hline grade $\mathrm{Cu}$ & copper grade & $\begin{array}{l}\text { weight \% } \\
\mathrm{Cu}\end{array}$ & new and revised data \\
\hline
\end{tabular}


Table 2. (continued)

\begin{tabular}{|c|c|c|c|}
\hline Field Name & Description & Units & Update comments \\
\hline $\mathrm{Cu}$ _metric tons & $\begin{array}{l}\text { amount of copper } \\
\text { produced or } \\
\text { estimated as a } \\
\text { resource }\end{array}$ & $\begin{array}{l}\text { metric } \\
\text { tons }\end{array}$ & new and revised data \\
\hline grade $\mathrm{Pb}$ & lead grade & $\begin{array}{l}\text { weight \% } \\
\mathrm{Pb}\end{array}$ & new and revised data \\
\hline $\mathrm{Pb} \_$metric_tons & $\begin{array}{l}\text { amount of lead } \\
\text { produced or } \\
\text { estimated as a } \\
\text { resource }\end{array}$ & $\begin{array}{l}\text { metric } \\
\text { tons }\end{array}$ & new and revised data \\
\hline grade Mo & molybdenum grade & $\begin{array}{l}\text { weight \% } \\
\text { Mo }\end{array}$ & new and revised data \\
\hline Mo_metric tons & $\begin{array}{l}\text { amount of } \\
\text { molybdenum } \\
\text { produced or } \\
\text { estimated as a } \\
\text { resource }\end{array}$ & $\begin{array}{l}\text { metric } \\
\text { tons }\end{array}$ & new and revised data \\
\hline grade $\mathrm{Zn}$ & zinc grade & $\begin{array}{l}\text { weight \% } \\
\mathrm{Zn}\end{array}$ & new and revised data \\
\hline Zn_metric_tons & $\begin{array}{l}\text { amount of zinc } \\
\text { produced or } \\
\text { estimated as a } \\
\text { resource }\end{array}$ & $\begin{array}{l}\text { metric } \\
\text { tons }\end{array}$ & new and revised data \\
\hline $\begin{array}{l}\text { production and resource } \\
\text { source reference and } \\
\text { comments }\end{array}$ & $\begin{array}{l}\text { source of production } \\
\text { data other than that } \\
\text { contained in MRDS } \\
\text { and the assumptions } \\
\text { and methods used to } \\
\text { derive some of the } \\
\text { production data; } \\
\text { multi-valued, } \\
\text { semicolon-delimited }\end{array}$ & & \\
\hline
\end{tabular}


Table 3. Explanation of codes used in the database.

\begin{tabular}{|l|l|}
\hline Field & Code Explanation \\
\hline state & ID - Idaho \\
& MT - Montana \\
\hline production & n - no \\
& y - yes \\
& r - resources only \\
null - not known \\
\hline significant & 1 - yes \\
& null - no \\
\hline USGS Model No. & see deposit model numbers of Cox and Singer \\
& (1986); Bliss (1992) for explanation. \\
\hline deposit type & 1 Polymetallic vein \\
& 2 Polymetallic carbonate replacement \\
& 3 Tertiary polymetallic vein \\
& 4 Skarn/contact metamorphic \\
& 5 Epithermal or hot spring \\
& 6 Porphyry Cu, Cu/Mo, or Mo \\
& 7 Butte Ag veins \\
& 8 Butte high-sulfidation Cu veins \\
& 9 Hg hot spring \\
& 10 Sb hot spring or veins \\
& 11 Alkaline epithermal precious metal \\
& 12 W vein \\
& 13 U or Th vein \\
& 14 Unknown-type epigenetic \\
& 15 Distal disseminated Au \\
& null - not known \\
\hline
\end{tabular}


Table 3. (continued)

\begin{tabular}{|c|c|}
\hline Field & Code Explanation \\
\hline value category & $\begin{array}{l}\text { Polymetallic veins and carbonate replacement } \\
\text { deposits (minor constituents in parenthesis) } \\
1 \mathrm{Au} \\
2 \mathrm{Ag} \\
3 \mathrm{Ag}-\mathrm{Pb}(\mathrm{Au}, \mathrm{Cu}, \mathrm{Zn}) \\
4 \mathrm{Cu}(\mathrm{Ag}, \mathrm{Pb}, \mathrm{Zn}) \\
5 \mathrm{Cu}, \mathrm{Pb}, \mathrm{Zn}(\mathrm{Ag}, \mathrm{Au}) \\
6 \mathrm{Au}-\mathrm{Pb}(\mathrm{Ag}, \mathrm{Cu}) \\
7 \mathrm{Zn} \\
\text { null - not known } \\
\text { Skarn/Contact metamorphic deposits } \\
\mathrm{B}-\mathrm{Pb}, \mathrm{Zn}, \mathrm{Ag} \\
\mathrm{Cu}-\mathrm{Cu} \\
\mathrm{Fe}-\mathrm{Fe} \\
\mathrm{Mo}-\mathrm{Mo} \\
\mathrm{P}-\text { precious metal }(\mathrm{Au}, \mathrm{Ag}) \\
\mathrm{W}-\mathrm{W} \\
\text { null - not known }\end{array}$ \\
\hline deposit style & $\begin{array}{l}1 \text { disseminated } \\
2 \text { veins, lenses, pods, stringers, shear zones } \\
3 \text { hot spring-disseminated } \\
4 \text { bedding replacement, manto, or irregular } \\
5 \text { breccia-hosted } \\
6 \text { stockwork } \\
7 \text { vein swarms } \\
\text { null - not known }\end{array}$ \\
\hline rock type & $\begin{array}{l}1 \text { felsic intrusion (granite to diorite) } \\
2 \text { volcanic } \\
3 \text { metamorphic } \\
4 \text { clastic sedimentary } \\
5 \text { carbonate } \\
6 \text { mafic intrusion (gabbro to ultramafic) } \\
7 \text { clastic sedimentary rocks of the Belt } \\
\text { Supergroup } \\
\text { null - not known }\end{array}$ \\
\hline reference & $\begin{array}{l}\text { number is keyed to reference in spreadsheet } 2 \\
\text { null - not known }\end{array}$ \\
\hline
\end{tabular}




\section{References}

Bliss, J.D., ed., 1992, Developments in mineral deposit modeling: U.S. Geological Survey Bulletin 2004, 168 p.

Bliss, J.D., 1994, Mineral deposit modeling using components for complex mineral deposits: mixed base- and precious-metal veins of the Idaho Batholith, Idaho: U.S. Geological Survey Open-File Report 94-690, 53 p.

Bookstrom, A.A., Johnson, B.R., Cookro, T.M., Lund, Karen,Watts, K.C., King, H.D., Kleinkopf, M.D., Pitkin, J.A., Sanchez, J.D., and Causey, J.D., 1998, Potential mineral resources, Payette National Forest, Idaho: Description and probabilistic estimation: U.S. Geological Survey Open-File Report 98-219a, 254 p.

Cox, D.P, and Singer, D.A., eds., 1986, Mineral Deposit Models: U.S. Geological Survey Bulletin 1693, 379p.

Elliot, J.E., Loen, J.S., Wise, K.K., Blaskowski, M.J., 1992, Map showing locations of mines and prospects in the Butte $1^{\circ} \times 2^{\circ}$ Quadrangle, western Montana, U.S. Geological Survey Investigations Series Map I-2050-C.

Fisher, F.S. and Johnson, K.M., eds., 1995, Geology and mineral resource assessment of the Challis $1^{\circ} \times 2^{\circ}$ quadrangle, Idaho; U.S. Geological Survey Professional Paper 1525

Gustafson, J., 1987, Mining districts of the State of Idaho: Idaho Bureau of Mines and Geology Map 6, 1:1,000,000.

Johnson, R., Close, T., and McHugh, E., 1998, Mineral resource appraisal of the Salmon National Forest, Idaho: U.S. Geological Survey Open-file Report 98-478.

Bruce R. Johnson, B.R., and Raines, G.L., 1995, Digital representation of the Idaho state geologic map: a contribution to the Interior Columbia Basin Ecosystem Management Project: U.S. Geological Survey Open-File Report 95-690.

Kness, R.F., 1995, Mineral Resources of the Targhee National Forest, Idaho and Wyoming: U.S. Bureau of Mines Mineral Land Assessment Open File Report 1295,43 p. 7

Lee, G.K., and others, 2000, Montana Geoenvironmental Explorer: U.S. Geological Survey Digital Data Series 65.

Long, K.R., DeYoung, J.H., Jr., and Ludington, S.D., 1998, Database of significant deposits of gold, silver, copper, lead and zinc in the United States; U.S. Geological Survey Open-file Report 98-206b.

Loen, J.S., and Pearson, R.C., 1989, Map showing locations of mines and prospects in the Dillon $1^{\circ}$ x $2^{\circ}$ quadrangle, Idaho and Montana: U.S. Geological Survey Miscellaneous Investigations Map I-1803-C, scale 1:25,000.

McHugh, E.L., Campbell, H.W., Horn, M.C., and Close, T.J., 1991, Mineral resource appraisal of the Challis National Forest, Idaho: U.S. Bureau of Mines Mineral Land Assessment Open File Report 6-91, 320 p.

Raines, G.L., and Johnson, B.R., 1995, Digital representation of the Montana state geologic map: U.S. Geological Survey Open-file Report 95-691. 
Spanski, G.T., 2004, Inventory of significant deposit occurrences in the Headwaters area in western Montana, Idaho, and extreme eastern Oregon and Washington: U.S. Geological Survey Open-file Report 2004-1038.

Tysdale, R.G., Ludington, S., and McCafferty, A.E., 1996, Mineral and energy resource assessment of the Helena National Forest, west-central Montana: U.S. Geological Survey Open-file Report 96-683-A.

Wilson, A.B., unpublished data, Mineral deposits in the Challis National Forest.

Worl, R.G., Link, P.K., Winkler, G.R., and Johnson, K.M., 1995, Geology and mineral deposits of the Hailey $1^{\circ} \times 2^{\circ}$ quadrangle and the western part of the Idaho Falls $1^{\circ} \times 2^{\circ}$ quadrangle: U.S. Geological Survey Bulletin 2064 